\section{Antitumorigenicity of xanthones-rich extract from Garcinia mangostana fruit rinds on HCT 116 human colorectal carcinoma cells}

\author{
Abdalrahim F.A. Aisha, ${ }^{1}$ Khalid M. Abu-Salah, ${ }^{2}$ Zeyad D. \\ Nassar, ${ }^{1}$ Mohammad J. Siddiqui, ${ }^{1}$ Zhari Ismail, ${ }^{2}$ Amin Malik \\ Shah Abdul Majid",
}

${ }^{1}$ School of Pharmaceutical Sciences, University Sains Malaysia, Malaysia,

${ }^{2}$ The Chair of Cancer Targeting and Treatment, Biochemistry Department and King Abdulla Institute for Nanotechnology, King Saud University, Saudi Arabia.

\begin{abstract}
This study aimed to investigate the antitumorigenicity of xanthones-rich extract from Garcinia mangostana L., Clusiaceae, fruit rinds which was obtained by a simple recrystallization of $75 \%$ ethanolic extract. $\alpha$-Mangostin content of the extract was determined qualitatively by TLC and quantitatively by HPLC, and total xanthones content was quantified by UV spectrophotometry. The extract was evaluated for cytotoxicity, apoptosis and antitumorigenicity on HCT 116 human colorectal carcinoma cells. $\alpha$-Mangostin was found to be the main constituent of the extract which was $71.2 \pm 0.1 \%$, and the total xanthones content was $95 \pm 4.8 \%$ (wt/ $\mathrm{wt}$ ). The extract showed potent dose dependent cytotoxicity with IC50 value $9.2 \mu \mathrm{g} /$ $\mathrm{mL}$. Apoptosis studies revealed activation of caspases 3 and 7, DNA fragmentation, chromatin condensation and loss of mitochondrial membrane potential. Studies on cell migration and colony formation indicate reduced cell migration ability and clonogenicity of treated HCT 116 cells at sub-inhibitory concentrations. Taken together, the cytotoxic effect of the xanthones extract is mediated through the mitochondrial pathway of apoptosis. The reduced cell migration and clonogenicity of HCT 116 cells might prevent both primary and metastatic tumor growth in vivo which will be the topic of our future work using the metastatic orthotopic colon cancer model.
\end{abstract}

Revista Brasileira de Farmacognosia Brazilian Journal of Pharmacognosy 21(6): 1025-1034, Nov./Dec. 2011
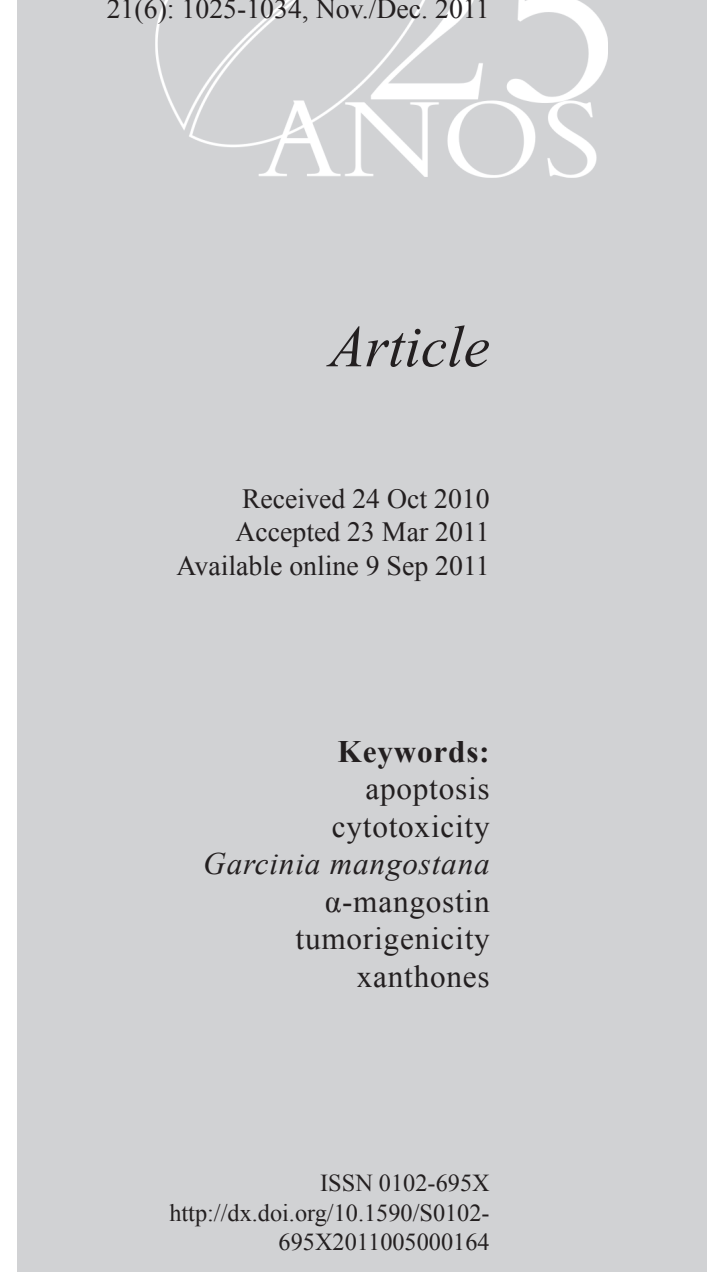

\section{Introduction}

Garcinia mangostana L. or mangosteen is a tropical tree from the family Clusiaceae. The tree is cultivated for centuries in the tropical rainforests of some Asian countries. The tree can be found now in Northern Australia, Brazil, Central America, Hawaii, Southern India, Indonesia, Malaysia, Thailand and other tropical countries ( $\mathrm{Ji}$ et al., 2007). The fruit is dark purple or reddish with soft, white and juicy edible pulp. The pericarps of the fruit have been used in folk medicine for the treatment of several human diseases including skin and wound infections, hemorrhoids, arthritis, tuberculosis, inflammation, mycosis, ulcers, genitourinary tract infections, fever, amoebic dysentery and abdominal pain (Baxter et al., 1999; Caius, 2003; Moongkarndi et al., 2004; Salguero, 2003; Suksamrarn et al., 2006). Mangosteen is also used worldwide as an ingredient of several commercial products including nutritional supplements, herbal cosmetics and pharmaceutical products (Ji et al., 2007).
The presence of high levels of xanthones in mangosteen fruit rinds was reported by several research groups (Ee et al., 2006; Peres et al., 2000; Zhang et al., 2010). $\alpha$-mangostin was the first xanthone isolated from $G$. mangostana and several other xanthones were isolated as well (Pedraza-Chaverri et al., 2008). Previous studies on different xanthones demonstrated remarkable pharmacological activities including analgesic (Cui et al., 2010), antioxidant (Jung et al., 2006), antiinflammatory (Chen et al., 2008; Tewtrakul et al., 2009), anticancer (Akao et al., 2008; Doi et al., 2009; Hung et al., 2009; Matsumoto et al., 2004), antiallergy (Nakatani et al., 2002), antibacterial (Chomnawang et al., 2009; Sakagami et al., 2005), antituberculosis (Suksamrarn et al., 2003), antifungal (Kaomongkolgit et al., 2009) and antiviral (Chen et al., 1996).

This study was performed to investigate the in vitro antitumorigenic activity of xanthones-rich extract from G. mangostana fruit rinds on human colorectal carcinoma cell line HCT 116. The motivation 
behind this study was to produce a cost effective but pharmacologically potent extract from the fruit rinds of $G$. mangostana using a simple and commercially applicable extraction method. This extract can be a good candidate for developing new noninvasive chemopreventive and therapeutic agent targeting colon cancer and other cancers as well.

\section{Material and Methods}

\section{Plant material}

Ripened fruits of Garcinia mangostana L., Clusiaceae, were obtained from a local fruit farm from the Island of Penang, Malaysia, in June 2009. Taxonomic authentication was done by Mr. Shanmugan A/C Vellosamy, Herbarium of School of Biology, USM, where a voucher specimen (11155) was deposited. The fruit rinds were separated from the edible pulp, dried at $45-50{ }^{\circ} \mathrm{C}$ for $24 \mathrm{~h}$ and grinded into fine powder. $60 \mathrm{~g}$ of the powdered material was extracted on a magnetic stirrer with $600 \mathrm{~mL} 75 \%$ ethanol: $25 \%$ water at $60{ }^{\circ} \mathrm{C}$ for $48 \mathrm{~h}$ with continuous shaking. After filtration ethanol was evaporated at $50{ }^{\circ} \mathrm{C}$ by rotavapor under vacuum, and the liquid residue was kept at $2-8{ }^{\circ} \mathrm{C}$ for $24 \mathrm{~h}$. A yellow precipitate was formed which was collected by filtration and dried at $45-50{ }^{\circ} \mathrm{C}$. The percent yield to the dried plant material was found to be $7.5 \%$ (wt/wt).

\section{Chemicals}

$\alpha$-Mangostin (97\% purity) was purchased from Chroma DEX Inc. Wizard ${ }^{\circledR}$ SV Genomic DNA Purification System and Caspase Glo 3/7 kit were purchased from Promega. 2,3-Bis (2-methoxy-4-nitro5-sulfophenyl)-2H-tetrazolium-5-carboxanilide inner salt (XTT) reagent, phenazine methosulfate (PMS), betulinic acid ( $90 \%$ purity), agarose, ethidium bromide, dimethyl sulfoxide (DMSO) were purchased from Sigma-Aldrich. HPLC grade solvents were purchased from Merck. Fetal bovine serum (FBS), penicillin/ streptomycin solution (PS) and RPMI-1640 cell culture medium were purchased from GIBCO BRL. TLC plates precoated with $0.25 \mathrm{~mm}$ layer of silica gel $60 \mathrm{~F}_{254}$ was obtained from Merck.

\section{Cell culture}

Human colorectal carcinoma HCT 116 cells (ATCC) were grown and maintained in RPMI 1640 medium with L-glutamine supplemented with $10 \% \mathrm{FBS}$, $100 \mu \mathrm{g} / \mathrm{mL}$ streptomycin, and $100 \mathrm{U} / \mathrm{mL}$ penicillin at $37^{\circ} \mathrm{C}$ in a humidified atmosphere of $5 \% \mathrm{CO}_{2}$

\section{Determination of $\alpha$-mangostin and total xanthones}

Firstly, the extract was analyzed on TLC as the following: $10 \mu \mathrm{L} \alpha$-mangostin or the xanthone extract at $1 \mathrm{mg} / \mathrm{mL}$ in methanol was spotted and allowed to dry. The chromatograms were developed under chamber saturation conditions with $n$-hexane: ethyl acetate: methanol at 7:3:0.5 v/v. After drying, the plates were visualized at 254 and $366 \mathrm{~nm}$. The identity of the band corresponding to $\alpha$-mangostin in the sample was confirmed by comparing the $\mathrm{R}_{\mathrm{f}}$ value with that of the reference compound.

Then $\alpha$-mangostin content of the extract was determined quantitatively by HPLC (Agilent 1100) as the following; $10 \mu \mathrm{L}$ of the extract or $\alpha$-mangostin at $1 \mathrm{mg} / \mathrm{mL}$ was separated on Nucleosil C18 $(5 \mu \mathrm{m}$, $4.6 \times 250 \mathrm{~mm}$ ) column at $25{ }^{\circ} \mathrm{C}$. The mobile phase was isocratic consisting of $90 \%$ acetonitrile and $10 \%$ $\left(0.1 \% \mathrm{H}_{3} \mathrm{PO}_{4}\right.$ in water $)$ at $1 \mathrm{~mL} / \mathrm{min}$. Separation time was $10 \mathrm{~min}$ and detection was performed at $254 \mathrm{~nm}$. The data acquisition was performed by ChemStation version A.08.03. The percentage of $\alpha$-mangostin in the extract was calculated based on the peak area. The total xanthones content of the extract was determined by UV spectrophotometry. Briefly, a calibration curve of $\alpha$-mangostin was prepared by plotting the absorbance at $260 \mathrm{~nm}$ versus the concentration. The absorbance of the extract was taken at $50 \mu \mathrm{g} / \mathrm{mL}$ in methanol and then the concentration was calculated by applying the linear regression equation of the standard calibration curve. The wt/wt percentage of total xanthones was calculated using the formula: (the calculated concentration $\mu \mathrm{g}$ / $\mathrm{mL} / 50 \mu \mathrm{g} / \mathrm{mL}) \times 100 \%$.

\section{Cell viability}

To determine cell viability, XTT assay was performed in 96-well plate format as described previously (Jost et al., 1992). Briefly, $1 \times 10^{4}$ cells were seeded in each well in $100 \mu \mathrm{L}$ culture medium. After overnight incubation, additional $100 \mu \mathrm{L}$ of fresh medium containing different concentrations of the xanthones extract or the positive controls ( $\alpha$-mangostin and betulinic acid) were added and further incubated for $48 \mathrm{~h}$. Afterwards, $20 \mu \mathrm{L}$ of a mixture of XTT and PMS at $1 \mathrm{mg} / \mathrm{mL}$ and $10 \mu \mathrm{g} / \mathrm{mL}$ was added to each well and incubated at $37{ }^{\circ} \mathrm{C}$ for $4 \mathrm{~h}$. The OD was measured at $450 \mathrm{~nm}$ by microplate reader (Thermolab Systems 354, Finland). The cell viability was calculated using the formula: ((OD ${ }_{450}$ samples-blank $) /\left(\mathrm{OD}_{450}\right.$ negative control-blank))x100\%. IC50 values were determined from the respective dose response curves $\pm \operatorname{SD}(n=3)$.

Effect on caspases 3 and 7 
Effect on caspase 3 and 7 was measured using caspase $3 / 7$ assay system according to supplier's instructions. Briefly, cells were seeded at $2 \times 10^{4} /$ well in $100 \mu \mathrm{L}$ medium in a white 96-well plate. After overnight incubation, cells were treated with the xanthones extract at $25 \mu \mathrm{g} / \mathrm{mL}$ for three time intervals viz. $45 \mathrm{~min}, 90 \mathrm{~min}$ and $180 \mathrm{~min}$. $\alpha$-mangostin was used as a positive control and the vehicle (DMSO) was used as a negative control. At the end of incubation, $100 \mu \mathrm{L}$ of caspase $3 / 7$ reagent was added to each well and further incubated at room temperature for $30 \mathrm{~min}$. Luminescence was measured by a microplate reader (Multitechnology Plate Reader type, 425-100 Finland). The results are presented as a mean of relative light units $(\mathrm{RLU}) \pm \mathrm{SD}(\mathrm{n}=4)$.

\section{DNA laddering assay}

$2 \times 10^{6}$ cells at $70-80 \%$ confluency were treated with the xanthones extract or $\alpha$-mangostin at $25 \mu \mathrm{g} / \mathrm{mL}$ for different intervals. At the end of each incubation period, cells were collected by centrifugation at 3000 rpm for $5 \mathrm{~min}$ and washed once with PBS. Total genomic DNA was extracted using Wizard ${ }^{\circledR}$ SV genomic DNA purification system and analyzed by electrophoresis on $1.2 \%$ agarose gel stained with $0.5 \mu \mathrm{g} / \mathrm{mL}$ ethidium bromide.

Effect on mitochondrial membrane potential and nuclear morphology

Mitochondrial staining with rhodamine 123 was performed in order to study the effect on mitochondrial membrane potential (Johnson et al., 1980), and nuclear morphology was examined by staining with Hoechst 33258 as previously described (Cheah et al., 2006; Chen et al., 2008). Briefly, 60-70\% confluent cultures of HCT 116 cells were treated with $\alpha$-mangostin or the xanthone extract at $25 \mu \mathrm{g} / \mathrm{mL}$ for 45,90 and $180 \mathrm{~min}$. Then the cells were washed with PBS and fixed with $4 \%$ paraformaldehyde for $20 \mathrm{~min}$. After washing with PBS, the cells were stained simultaneously for $20 \mathrm{~min}$ with rhodamine 123 and Hoechst 33258 at $1 \mu \mathrm{g} / \mathrm{mL}$ and $10 \mu \mathrm{g} / \mathrm{mL}$, respectively. The stained cells were washed extensively with PBS and the morphology of cells was examined immediately under x20 magnification of fluorescent microscope supplied with digital camera (IX71, Olympus). The morphological changes of treated cells were evaluated by studying 25 randomly selected microscopic fields. The apoptotic index was calculated for each microscopic field using the formula: (the number of apoptotic cells/ the total cell count) $\times 100 \%$ and the results are presented as mean $\pm \mathrm{SD}$.

\section{Effect on migration of HCT 116 cells}

Effect on migration ability of HCT 116 cells was studied by wound healing assay as described previously (Liang et al., 2007). Briefly, cells were prepared in a single cell suspension and seeded in 6 -well plate at $1 \times 10^{6}$ cells/well in $3 \mathrm{~mL}$ medium. After $48 \mathrm{~h}$ when cells reach $100 \%$ confluency, a scratch was made along the middle line of each well with sterile $200 \mu \mathrm{L}$ micropipette tip. The edges of the scratch were smoothened by cell culture medium and the detached cells were washed out with PBS. Afterwards, $3 \mathrm{~mL}$ cell migration medium containing $2 \% \mathrm{FBS}$ and the treatment compounds was immediately added. The scratches were photographed at zero time at $\mathrm{x} 4$ magnification in inverted light microscope with digital camera and after $18 \mathrm{~h}$. Leica Quin software was used to measure the width of the cell-free area of minimum 100 points/ well. The average percentage of wound closure of three independent experiments was calculated relatively to zero time using the formula: (1- (the width at $18 \mathrm{~h} /$ the width at zero time)) $\mathrm{x} 100 \%$.

\section{Effect on clonogenicity of HCT 116 cells}

Effect on clonogenicity of HCT 116 cells was evaluated by the colony formation assay as previously described (Franken et al., 2006). 1000 single suspended cells were seeded in 6 -well plate at $2.5 \mathrm{~mL} /$ well. After overnight incubation, the old medium was replaced with a fresh one containing different concentrations of the extract $10,7.5,5$ and $2.5 \mu \mathrm{g} / \mathrm{mL}$. After $48 \mathrm{~h}$, the medium containing the treatment compounds was removed and the cells were washed twice with PBS and a fresh medium was added. Then the cells were incubated for 12 days to allow colonies to form. At the end of incubation, the colonies were fixed in $4 \%$ paraformaldehyde and stained with $0.5 \%$ crystal violet. The number of colonies of more than 50 cells was counted using a stereomicroscope. The plating efficiency (PE) of untreated cells was determined as the following: (the number of formed colonies/ the number of seeded cells) x $100 \%$. The survival fraction (SF) of treated cells was calculated using the formula: ((the number of formed colonies after treatment/(the number of seeded cells x PE)) X 100\% ( $n=3)$. $\alpha$-mangostin at 5 $\mu \mathrm{g} / \mathrm{mL}$ was used as a positive control.

\section{Statistical analysis}

Statistical analysis was carried out with the SPSS 16.0 for Windows software package. The results are expressed as the mean \pm SD. One way ANOVA with Dunnett test were used to compare the means, and differences were considered significant at $p<0.05$. 


\section{Results}

Determination of $\alpha$-mangostin and total xanthones

The UV spectra of $\alpha$-mangostin and the xanthone extract were collected in the wavelength range of 500-200 $\mathrm{nm}$ (Figure 1a). The figure indicates almost identical spectra which provide the basis for quantitative analysis of total xanthones. Analysis in TLC indicates $\alpha$-mangostin as the main constituent of the extract (Figure 1b). In HPLC analysis the retention time was found to be $5.52 \pm 0.02 \mathrm{~min}$ for both $\alpha$-mangostin standard and that from the extract which further confirms the identity of the compound (Figure $1 \mathrm{c}$ and 1d).Quantitative analysis in HPLC shows that $\alpha$-mangostin is present at $71.2 \pm 0.1 \%$. Concentration of xanthones in the extract was quantified by applying the linear regression equation of $\alpha$-mangostin calibration curve $\left(\mathrm{y}=0.0662 \mathrm{x}-0.0205, \mathrm{R}^{2}=0.9935\right)$. The calculated $\mathrm{wt} / \mathrm{wt}$ percentage of total xanthones in the extract was $95 \pm 4.8 \%(\mathrm{n}=4)$.
The xanthones extract exhibited potent cytotoxic effect on HCT 116 cells

Cell viability was measured following 48 $\mathrm{h}$ treatment at seven concentration points $25,20,15$, $12.5,10,7.5$ and $5 \mu \mathrm{g} / \mathrm{mL}$. $\alpha$-Mangostin and betulinic acid were used as positive control. Figure 2 a shows that the test compounds exhibit strong cytotoxic activity in a dose dependent manner. Analysis of the dose response curves indicates low IC50 values of $\alpha$-mangostin $6.6 \pm 0.1 \mu \mathrm{g} / \mathrm{mL}$. The IC50 of the xanthone extract was $9.2 \pm 0.09 \mu \mathrm{g} / \mathrm{mL}$ and was equivalent to that of betulinic acid which was $8.7 \pm 0.9 \mu \mathrm{g} / \mathrm{mL}(\mathrm{n}=3)$.

The xanthones extract enhanced caspases 3 and 7 activity

Activity of the executioner caspases was significantly induced by treating HCT 116 cells with both the extract and the positive control at $25 \mu \mathrm{g} / \mathrm{mL}$ in time dependent manner (Figure 2b). Statistical analysis

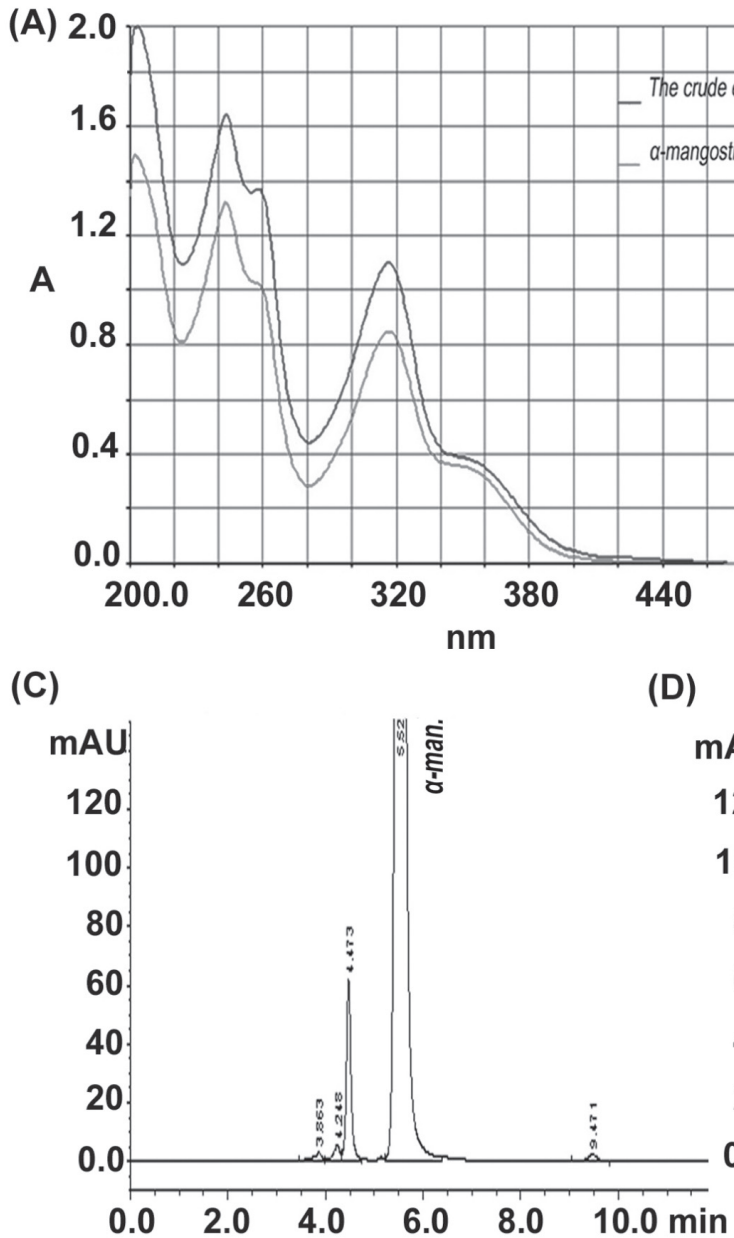

(B)

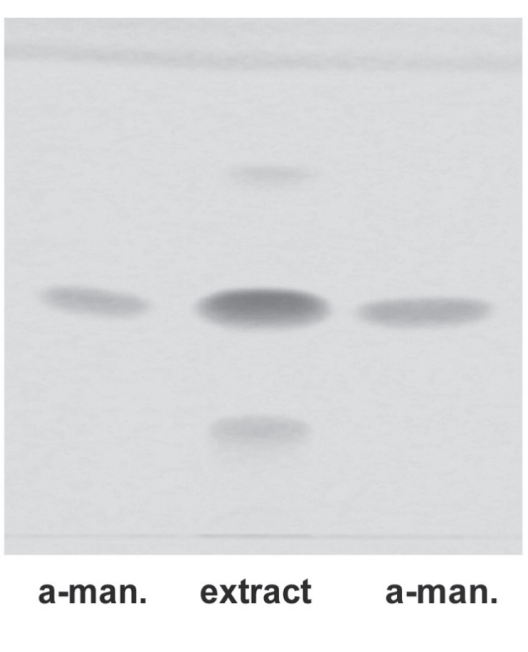

(D)

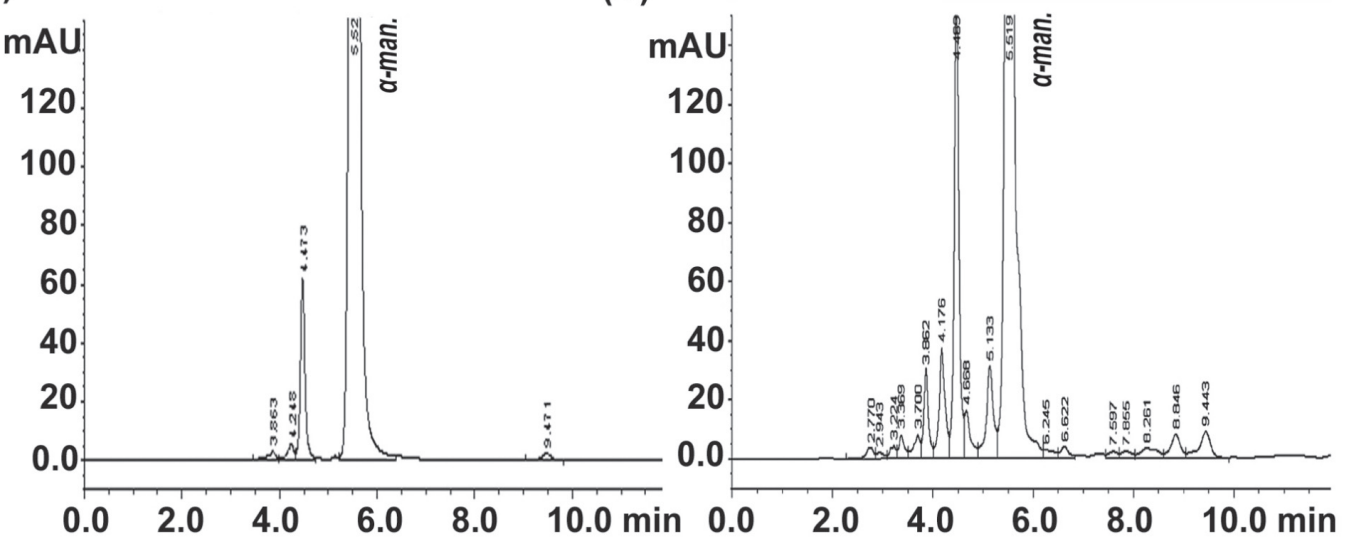

Figure 1 Fingerprints of $\alpha$-mangostin and the xanthone crude extract. UV spectra (a), TLC fingerprints of $\alpha$-mangostin and the xanthones extract (b). HPLC profile of $\alpha$-mangostin (c) and xanthones extract (d). 
by One way ANOVA and Dunnett test using untreated cells as reference indicates significant enhancement of caspases 3 and 7 activity as early as $45 \mathrm{~min}$ of treatment, $p$ values $=0.0$

\section{The xanthones extract induced DNA fragmentation}

We looked into the ability of the xanthones extract to cause DNA fragmentation of HCT 116 cells as a late marker of apoptosis. Treatment of cells with the extract caused apparent DNA degradation. A characteristic DNA ladder was produced on agarose gel electrophoresis which was detected early after $6 \mathrm{~h}$ of treatment. Untreated cells show the presence of intact DNA characterized by the presence of a single band (Figure 2c).

Effect on mitochondrial membrane potential and nuclear morphology

In order to study the apoptotic pathway induced by the extract, we investigated effect of the extract on mitochondrial membrane potential of HCT 116 cells. Microscopic examination revealed altered mitochondrial potential of treated cells compare to untreated cells. Figure 3 shows more brightly stained and swollen mitochondria of treated cells (apoptotic) which is lacking in untreated cells. The bar chart analysis reveals a time dependent and significant increment in the apoptotic index of treated cells compare to untreated cells, $p$ values $=0.0$.

Staining of HCT 116 cells with Hoechst 33258 resulted in differential morphological appearance of treated cells. Cells treated with the vehicle only (DMSO) showed normal nuclei morphology characterized by weak intensity fluorescence with uniformly stained DNA. On the other hand, the treated cells showed clear apoptotic morphology characterized by either single intense fluorescence or multiple strong fluorescence signals in the cell nuclei (Figure 4). The apoptotic index was calculated in each interval and compared to untreated cells, the results indicate that the treatment compounds caused a significant and time dependent induction of chromatin condensation, $p$ values $=0.0$.

\section{The xanthones extract inhibited cell migration}

We examined the effect of the extract on migration ability of HCT 116 cells by wound healing assay. The percent of wound closure in the presence and absence of treatment compounds was calculated after $18 \mathrm{~h}$ relatively to the zero time. The wound of untreated cells was closed by $64 \pm 5 \%$. Wound closure was significantly reduced by treatment with the extract in a dose dependent manner, the percent wound closure

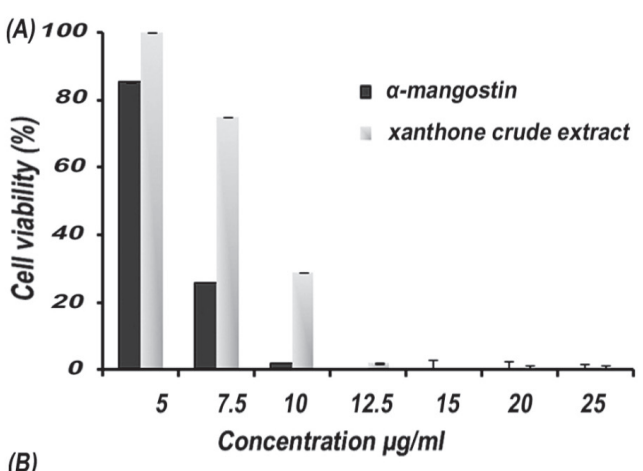

(B)

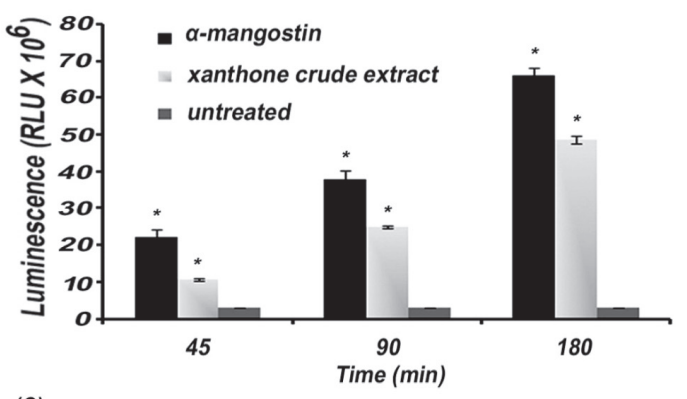

(C)

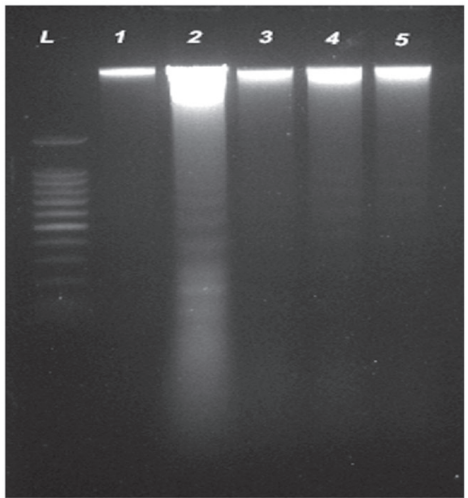

Figure 2. Effect on cell viability and apoptosis markers. Both treatments reduced cell viability in a dose dependent manner (a), enhancement of caspases 3 and 7 in time dependent manner (b) and induction of DNA fragmentation of HCT 116 cells (c), L (DNA ladder), 1 (untreated cells), 2 ( $\alpha$-mangostin), 3, 4 and 5 for the xanthones crude extract $(6,12$ and $24 \mathrm{~h}$ treatments).

was $27 \pm 7 \%$ at $10 \mu \mathrm{g} / \mathrm{mL}, 32 \pm 7 \%$ at $7.5 \mu \mathrm{g} / \mathrm{mL}$ and $52 \pm 7 \%$ at $5 \mu \mathrm{g} / \mathrm{mL}(p=0.0)$. No significant difference was found when the pure compound ( $\alpha$-mangostin) was compared with the extract at the same concentration point $(p=0.532)$.

The xanthones extract decreased clonogenicity of HCT 116 cells

Effect on clonogenicity of HCT 116 cells was investigated by colony formation assay. The PE of untreated cells was $50 \pm 1.4 \%$. Dose dependent reduction of the SF was obtained by treating the cells with the xanthone extract; the SF at 10, 7.5, 5 and 2.5 
$\mu \mathrm{g} / \mathrm{mL}$ was $2.2 \pm 0.3,26 \pm 1.7,48 \pm 7.5$ and $76 \pm 7.3 \%$, respectively. The SF of $\alpha$-mangostin treated cells at $5 \mu \mathrm{g} / \mathrm{mL}$ was $48.8 \pm 3.6 \%$. Statistical analysis indicate that clonogenicity of HCT 116 cells was significantly reduced in all treatments compare to untreated cells $(p=0.0)$. No significant difference was found between $\alpha$-mangostin and the extract at $5 \mu \mathrm{g} / \mathrm{mL},(p=0.158)$.

\section{Discussion}

In this study, we report antitumorigenic effects
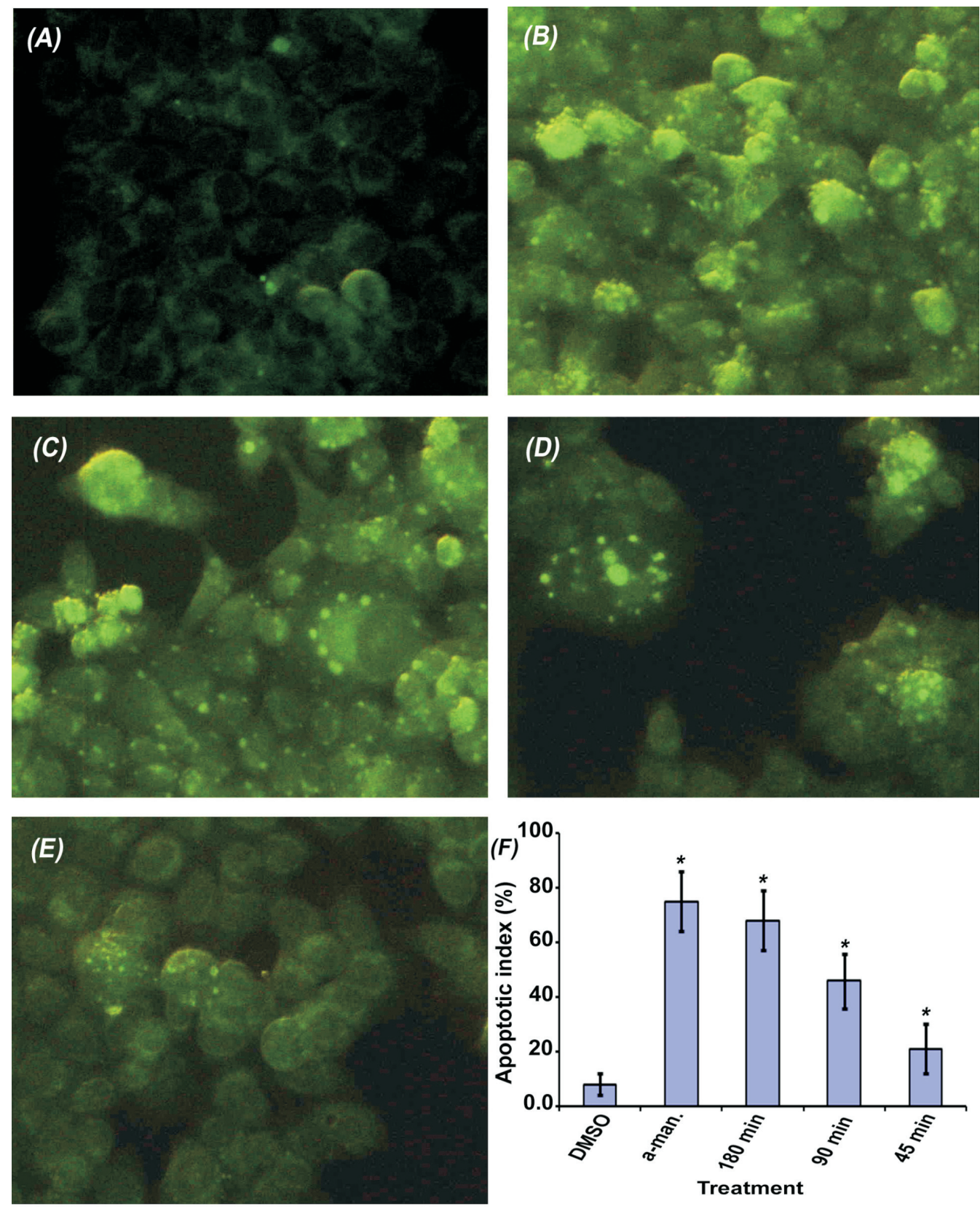

Figure 3. Effect on mitochondrial membrane potential. Untreated cells (a), and the treated cells with; $\alpha$-mangostin (b), the extract for $180 \mathrm{~min}(\mathrm{c}), 90 \mathrm{~min}(\mathrm{~d}), 45 \mathrm{~min}(\mathrm{e})$ and a bar chart showing the apoptotic index of each treatment (f) (* indicates $p$ value $<0.05$ ). 
the extract and it was reported previously as apoptotic compound (Matsumoto et al., 2004; Matsumoto et al., 2003). Betulinic acid was selected as positive control for the cytotoxicity study because it is a cytotoxic compound from natural origin. Dose dependent cytotoxicity was obtained at seven doses of all treatments, the IC50 value of the extract was achieved at $9.2 \pm 0.09 \mu \mathrm{g} / \mathrm{mL}$. Cytotoxicity of the extract was equivalent to that of betulinic acid which shows IC50 value of $8.7 \pm 0.9 \mu \mathrm{g}$ / $\mathrm{mL}$

On the basis of cytotoxicity results we carried out more advanced experiments to investigate the effect on both early stage and late stage apoptosis markers. The apoptosis experiments were performed at $25 \mu \mathrm{g} / \mathrm{mL}$ since this concentration was found to induce apoptotic cell death after short period of treatment and since the experiments were carried out in short term manner. Lower concentrations but above IC50 could be used, however the time required for detection of early signals of apoptosis activation will be increased as well. We studied the effect on the executioner caspases 3 and 7 as early markers of apoptosis; the results show
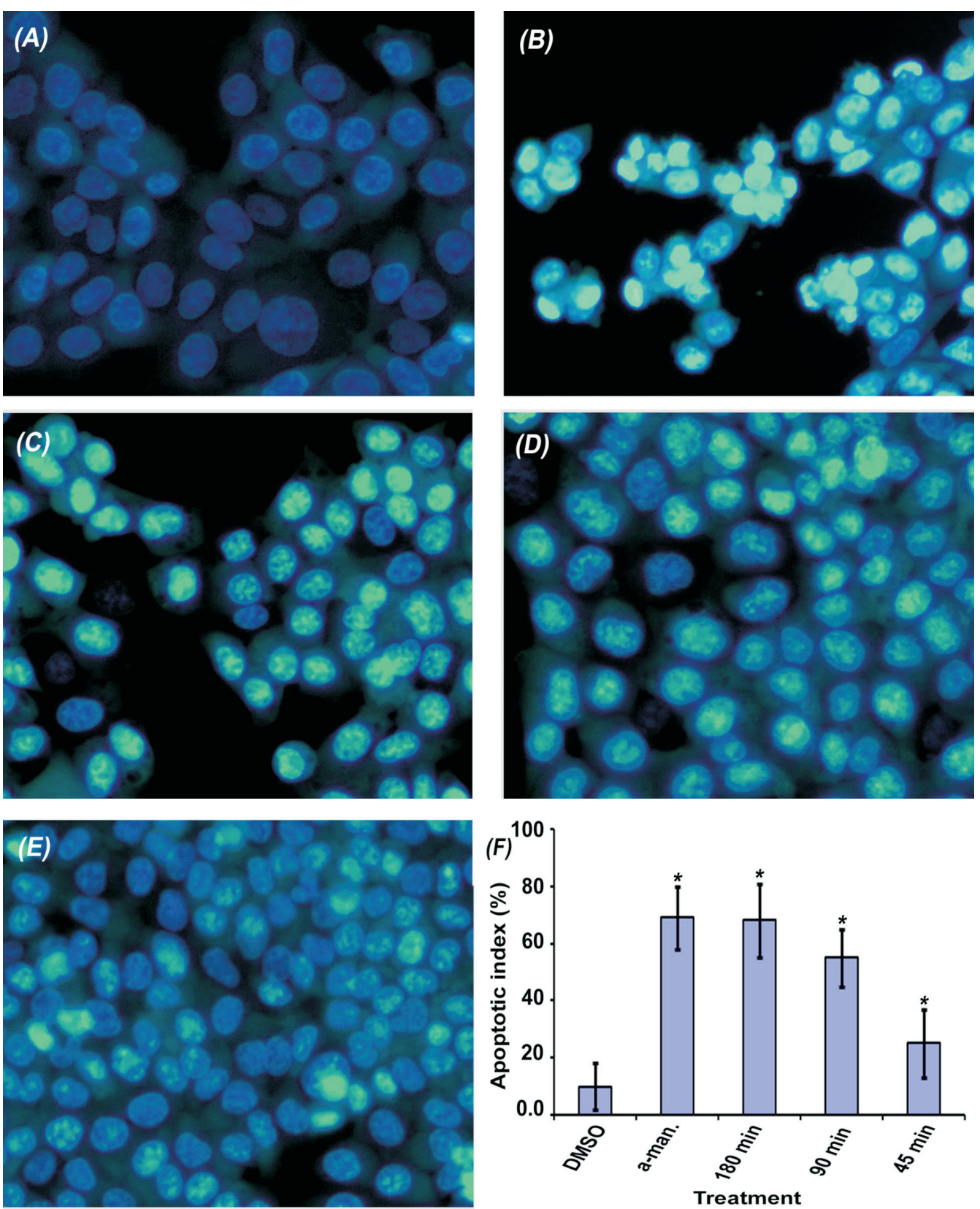

Figure 4. Effect on nuclear morphology of HCT 116 cells. Untreated cells (a), and the treated cells with; $\alpha$-mangostin (b), the extract for $180 \mathrm{~min}(\mathrm{c}), 90 \mathrm{~min}(\mathrm{~d}), 45 \mathrm{~min}(\mathrm{e})$ and a bar chart showing the apoptotic index of each treatment (f) (* indicates $p$ value $<0.05$ ). 
that these proenzymes were activated as early as $45 \mathrm{~min}$ after treatment (Figure 2b). Following that, we studied the effect on late stage events of apoptosis including DNA fragmentation and nuclear condensation. DNA fragmentation was clearly obvious after $6 \mathrm{~h}$ incubation (Figure 2c). Induction of nuclear condensation was also observed in a time dependent manner providing further confirmation on the activation of apoptotic cell death machinery (Figure 4). In order to explore which apoptotic pathway is involved, we looked into the effect on mitochondrial membrane potential. Treated cells appeared more brightly stained than untreated cells (Figure 3), which indicate lower concentration of the cationic dye in mitochondria relatively to the cytoplasm. This indicates loss of mitochondrial membrane potential which considered as early stage in the activation of mitochondrial pathway of apoptosis that precedes cytochrome $\mathrm{c}$ release and activation of different caspases (Scarlett et al., 2000). Based on these findings, we can conclude that the apoptotic potential of the xanthones crude extract and $\alpha$-mangostin was mediated through activation of the intrinsic (mitochondrial) pathway of apoptosis.

Since treatment of HCT 116 cells with high concentrations of the xanthone extract resulted in potent cytotoxic and apoptotic effects, we found it essential to investigate the effects at sub-cytotoxic concentrations. The treated cells at these concentrations did not reveal any sings of cytotoxicity but showed a reduced migration ability (Figure 5). This result highlights the anti-metastatic potential of the xanthone extract. In studies that looked into reversibility of cytotoxic effect
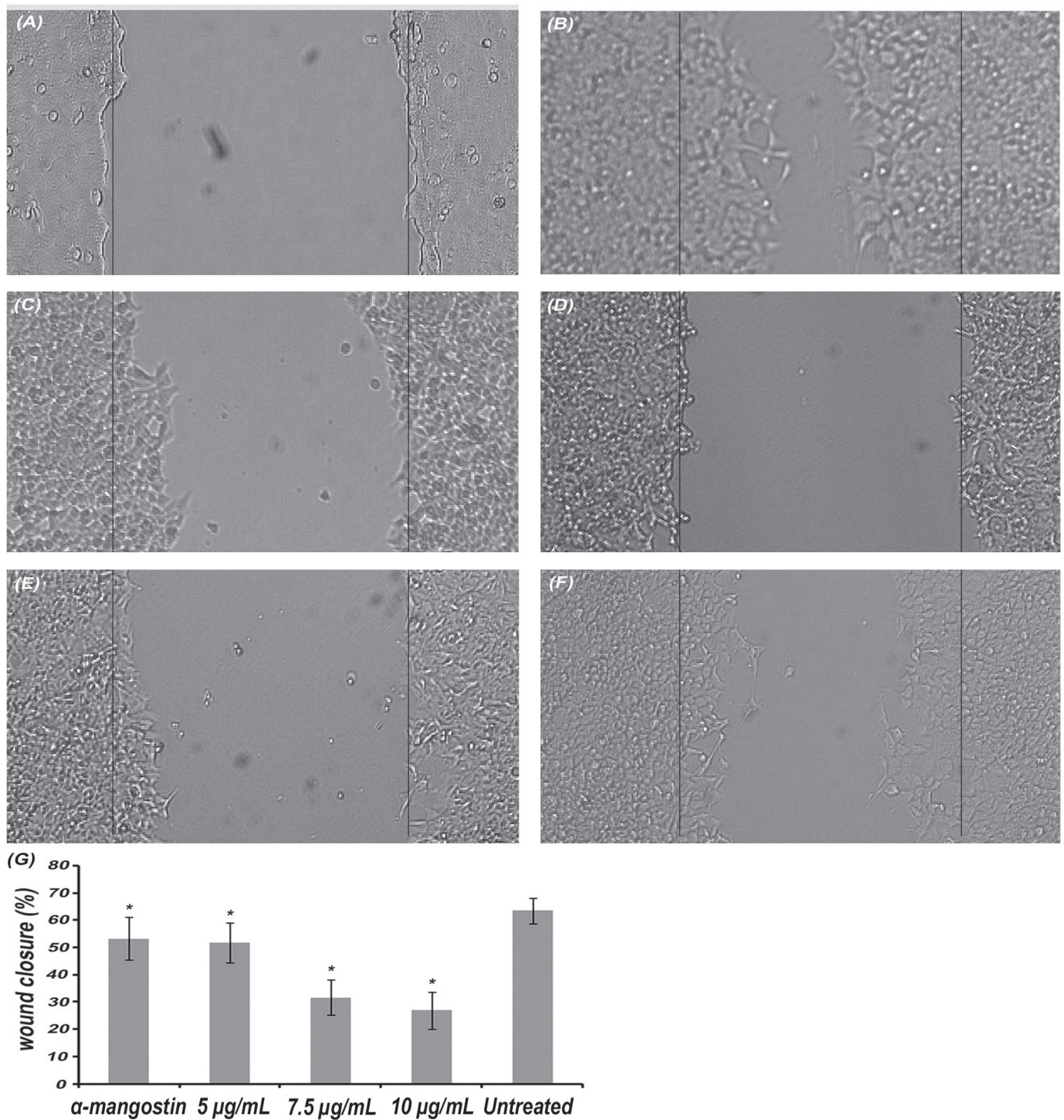

Figure 5. Effect on cell migration ability of HCT 116 cells. Zero time (a), and the cells after 18 h; untreated cells (b), $\alpha$-mangostin at $5 \mu \mathrm{g} / \mathrm{mL}$ (c), the extract at $10 \mu \mathrm{g} / \mathrm{mL}$ (d), the extract at $7.5 \mu \mathrm{g} / \mathrm{mL}$ (e), the extract at $5 \mu \mathrm{g} / \mathrm{mL}$ (f) and a bar chart showing analysis of the percent wound closure relatively to zero time $(\mathrm{g})(*$ indicates $p$ value $<0.05$ ). 
of the extract, we observed irreversible cell damage and significant reduction in the clonogenic potential of HCT 116 cells (Figure 6). Overall, we report a novel xanthone extract from $G$. mangostana fruit rinds with cytotoxic, apoptotic, with potential anti-metastatic effect. This extract might provide effective prevention

and treatment of the metastatic colon cancer. However, this extract suffers the low aqueous solubility $(<0.5 \mu \mathrm{g} /$ $\mathrm{mL}$ ) and probably low oral bioavailability as reported previously (Li et al., 2011). Therefore, reliable in vivo results could be obtained only after improving its aqueous solubility which will be the topic of our future work.
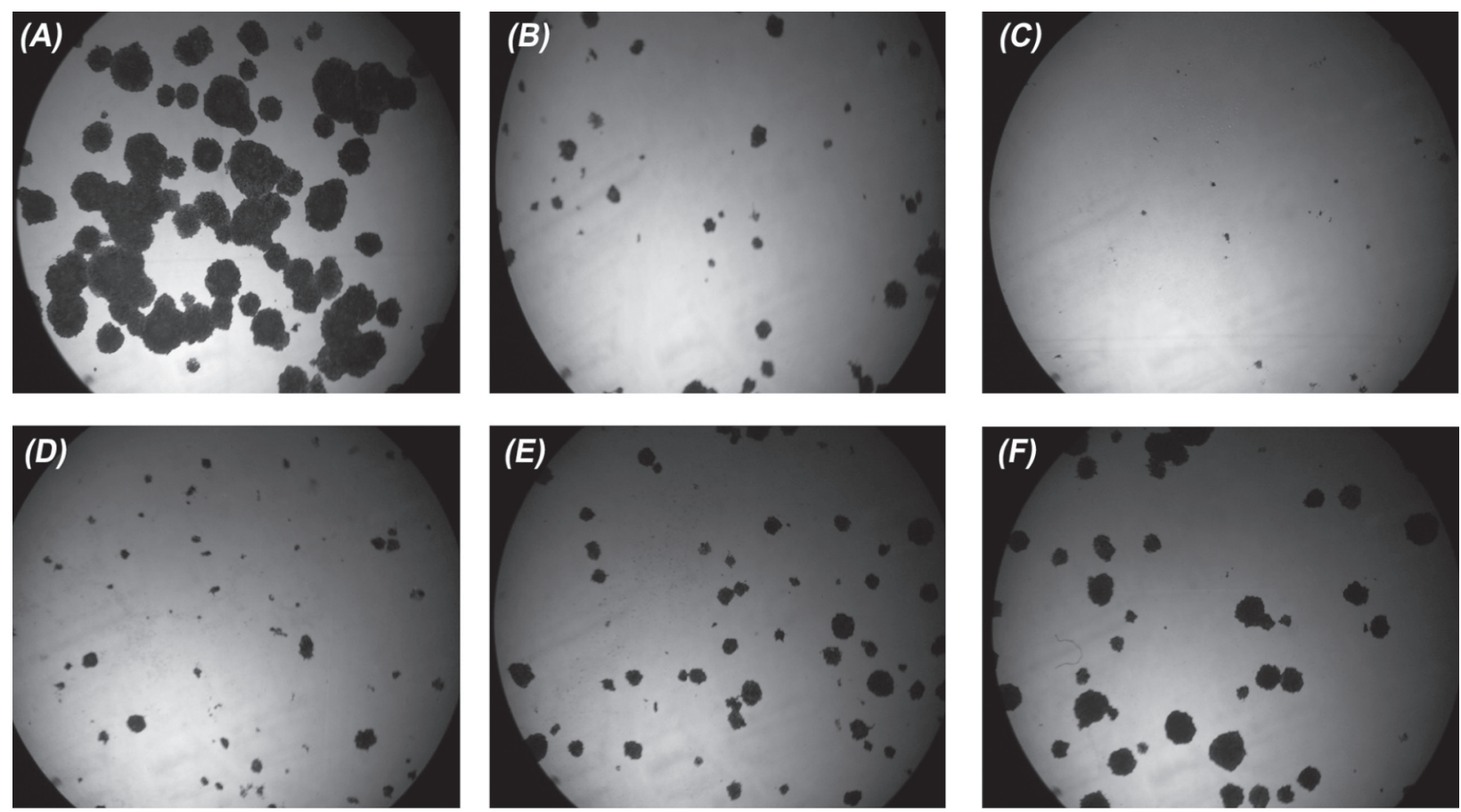

Figure 6. Effect on clonogenicity of HCT 116 cells. Untreated cells (a), $\alpha$-mangostin at $5 \mu \mathrm{g} / \mathrm{mL}$ (b), the extract at $10 \mu \mathrm{g} / \mathrm{mL}$ (c), the extract at $7.5 \mu \mathrm{g} / \mathrm{mL}$ (d), the extract at $5 \mu \mathrm{g} / \mathrm{mL}$ (e) and the extract at $2.5 \mu \mathrm{g} / \mathrm{mL}$ (f).

\section{Acknowledgements}

This work was supported by University Sains Malaysia, science fund number 305/ PFARMASI/613219 and by FRGS-MOE fund number 203/PFARMASI/61154; and partially by the research chair of "Drug Targeting and Treatment of Cancer using Nanoparticles" at king Saud University, Riyadh, Saudi Arabia. The first and the third authors would like to acknowledge with thanks Universiti Sains Malaysia for providing scholarship under the fellowship program for 2010. Finally, we would like to thank Mr. Shanmugan A/C Vellosamy for authentication of the plant.

\section{References}

Akao Y, Yoshihito N, Munekazu L, Yshinori N 2008. Anticancer Effects of Xanthones from Pericarps of Mangosteen. Int J Mol Sci 9: 355-370.

Baxter H, Harborne J, Moss G 1999. Phytochemical Dictionary - A Handbook of Bioactive Compounds from Plants. Taylor \& Francis 590.
Caius JF 2003. The Medicinal and Poisonous Plants of India. Scientific Publishers, India.

Cheah Y, Azimahtol H, Abdullah N 2006. Xanthorrhizol exhibits antiproliferative activity on MCF-7 breast cancer cells via apoptosis induction. Anticancer Res 26: 4527-4534.

Chen J, Peng H, Ou-Yang X, He X 2008. Research on the antitumor effect of ginsenoside Rg3 in B16 melanoma cells. Melanoma Res 18: 322-329.

Chen L-G, Yang L-L, Wang C-C 2008. Anti-inflammatory activity of mangostins from Garcinia mangostana. Food Chem Toxicol 46: 688-693.

Chen S, Wan M, Loh B 1996. Active constituents against HIV-1 protease from Garcinia mangostana. Planta Med 62: 381-382.

Chomnawang M, Surassmo S, Wongsariya K, Bunyapraphatsara N 2009. Antibacterial Activity of Thai Medicinal Plants against Methicillin-resistant Staphylococcus aureus. Fitoterapia 80: 102-104.

Cui J, Hu W, Cai Z, Liu Y, Li S, Tao W, Xiang H 2010. New medicinal properties of mangostins: analgesic activity and pharmacological characterization of active ingredients from the fruit hull of Garcinia mangostana L. Pharmacol Biochem Be 95: 166-172. 
Doi H, Shibata M, J Shibata E M, Akao Y, Iinuma M, Tanigawa N, Otsuki Y 2009. Panaxanthone isolated from pericarp of Garcinia mangostana L. suppresses tumor growth and metastasis of a mouse model of mammary cancer. Anticancer Res 29: 2485-2495.

Ee G, Daud S, Taufiq-Yap Y, Ismail N, Rahmani M 2006. Xanthones from Garcinia mangostana (Guttiferae). Nat Prod Res 12: 1067-1073.

Franken NP, Rodermond H, Stap J, Haveman J, Bree C 2006. Clonogenic assay of cells in vitro. Nat Protoc 1: 2315-2319.

Hung S, Shen K, Wu C, Liu C, Shih Y 2009. Alpha-mangostin suppresses PC-3 human prostate carcinoma cell metastasis by inhibiting matrix metalloproteinase2/9 and urokinase-plasminogen expression through the JNK signaling pathway. J Agric Food Chem 57: 1291-1298.

Ji X, Avula B, Khan IA 2007. Quantitative and qualitative determination of six xanthones in Garcinia mangostana L. by LC-PDA and LC-ESI-MS. J Pharmaceut Biomed 43: $1270-1276$

Johnson L, Walsh M, Chen L 1980. Localization of mitochondria in living cells with rhodamine 123. Proc Natl Acad Sci 77: 990-994.

Jost L, Kirkwood J, Whiteside T 1992. Improved shortand long-term XTT-based colorimetric cellular cytotoxicity assay for melanoma and other tumor cells. J Immunol Methods 4: 153-165.

Jung H, Su B, Keller W, Mehta R, Kinghorn A 2006. Antioxidant xanthones from the pericarp of Garcinia mangostana (Mangosteen). J Agric Food Chem 54: 2077-2082.

Kaomongkolgit R, Jamdee K, Chaisomboon N 2009 Antifungal activity of alpha-mangostin against Candida albicans. J Oral Sci 51: 401-406.

Li L, Brunner I, Han AR, Hamburger M, Kinghorn AD, Frye R, Butterweck V 2011. Pharmacokinetics of alpha-mangostin in rats after intravenous and oral application. Mol Nutr Food Res.

Liang C-C, Park A, Guan J-L 2007. In vitro scratch assay: a convenient and inexpensive method for analysis of cell migration in vitro. Nat Protoc 2: 329-333.

Matsumoto K, Akao Y, Yi H, Ohguchi K, Ito T, Tanaka T, Kobayashi E, Iinuma M, Nozawa Y 2004. Preferential target is mitochondria in [alpha]-mangostin-induced apoptosis in human leukemia HL60 cells. Bioorgan Med Chem 12: 5799-5806.

Matsumoto K, Akao Y, Kobayashi E, Ohguchi K, Ito T, Tanaka T, Iinuma M, Nozawa Y 2003. Induction of apoptosis by xanthones from mangosteen in human leukemia cell lines. J Nat Prod 66: 1124-1127.

Moongkarndi P, Kosem N, Kaslungka S, Luanratana O, Pongpan N, Neungton N 2004. Antiproliferation, antioxidation and induction of apoptosis by Garcinia mangostana (mangosteen) on SKBR3 human breast cancer cell line. J Ethnopharmacol 90: 161-166.

Nakatani K, Atsumi M, Arakawa T, Oosawa K, Shimura S, Nakahata N, Ohizumi Y 2002. Inhibitions of histamine release and prostaglandin E2 synthesis by mangosteen, a Thai medicinal plant. Biol Pharm Bull 25: 1137-1141.

Pedraza-Chaverri J, Cárdenas-Rodríguez N, Orozco-Ibarra M, Pérez-Rojas J 2008. Medicinal properties of mangosteen (Garcinia mangostana). Food Chem Toxicol 46: 3227-3239.

Peres V, Nagem T, Oliveira Fd 2000. Tetraoxygenated naturally occurring xanthones. Phytochemistry 55: $683-710$

Rajput A, Dominguez San Martin I, Rose R, Beko A, Levea C, Sharratt E, Mazurchuk R, Hoffman RM, Brattain MG, Wang J 2008. Characterization of HCT116 human colon cancer cells in an orthotopic model. $J$ Surg Res 147: 276-281.

Sakagami Y, Iinuma M, Piyasena K, Dharmaratne H 2005. Antibacterial activity of alpha-mangostin against vancomycin resistant Enterococci (VRE) and synergism with antibiotics. Phytomedicine 12: 203208.

Salguero C 2003. A Thai Herbal. Findhorn Press 118.

Scarlett J, Sheard P, Hughes G, Ledgerwood E, Ku H-H, Murphy M 2000. Changes in mitochondrial membrane potential during staurosporine-induced apoptosis in Jurkat cells. FEBS Lett 475: 267-272

Suksamrarn S, Komutiban O, Ratananukul P, Chimnoi N, Lartpornmatulee N, Suksamrarn A 2006. Cytotoxic prenylated xanthones from the young fruit of Garcinia mangostana. Chem Pharm Bull 54: 301-305.

Suksamrarn S, Suwannapoch N, Phakhodee W, Thanuhiranlert J, Ratananukul P, Chimnoi N, Suksamrarn A 2003. Antimycobacterial activity of prenylated xanthones from the fruits of Garcinia mangostana. Chem Pharm Bull 51: 857-859.

Tewtrakul S, Wattanapiromsakul C, Mahabusarakam W 2009. Effects of compounds from Garcinia mangostana on inflammatory mediators in RAW264.7 macrophage cells. J Ethnopharmacol 121: 379-382.

Zhang Y, Song Z, Hao J, Qiu S, Xu Z 2010. Two new prenylated xanthones and a new prenylated tetrahydroxanthone from the pericarp of Garcinia mangostana. Fitoterapia 81: 595-599.

\section{*Correspondence}

Dr. Amin Malik Shah Abdul Majid

School of Pharmaceutical Sciences, University Sains Malaysia (USM).

Minden 11800, Pulau Pinang, Malaysia.

aminmalikshah@usm.my

Phone: +6046534582 Fax: +6046534582 